\title{
Exotic Plants in Theodore Roosevelt NATIONAL PARK
}

\author{
JACK L. BUTLER $\bullet$ FRANK A. EINHELLIG \\ DEPARTMENT OF BIOLOGY $\bullet$ UNIVERSITY OF SOUTH DAKOTA \\ VERMILLION
}

\section{$\checkmark \quad$ ProjeCt SUMMARY}

The primary objective of the first year of the project was to determine the number and distribution of exotic plant species within the park. A preliminary list of exotics was provided by park personal. A more complete list of exotics found in the park was then generated using Heidel's (1990) list of "Preliminary Vascular Flora of Theodore Roosevelt National Park". The origin of all of the plant species listed in that report were determined from Stevens (1963) and Flora of the Great Plains (Great Plains Association 1986).

A total of 57 species, representing 18 families, of exotic plants have been identified as occurring within Theodore Roosevelt National Park (Table 1). Park personnel initially provided a list of 31 species of exotic plants. This initial list increased to 52 species when the origin of the preliminary vascular flora of Heidel (1990) was examined. Five species were recorded during the 1991 field season as new additions to both the initial list provided by park personnel and the preliminary flora list reported by Heidel (1990).

A systematic search of both the North and South Units was conducted using the functional management units as described by Marlowe et al. (1984) and Heidel (1990). An effort was made to traverse as much of the Park as possible. A rather intensive survey was first made of most of the watershed that comprises Jules Creek. The dominant exotic species found during this survey was leafy spurge (Euphorbia esula), with smaller populations of Canada thistle (Cirsium arvense). Other exotics were noted during the survey and included yellow sweet clover (Melilotus officinalis), smooth brome (Bromus inermis) and, Kentucky bluegrass (Poa pratensis). An attempt was initially made to map each infested leafy spurge site onto U.S.G.S. 7.5-minute topographic maps. However, the high density of the infestations and the low resolution of the maps prevented accurate identification of specific infested sites on the topographic maps, hence an alternative approach was used. The surveyed area was subdivided into segments and the infestations grouped by segments. The density of Canada thistle infestations was lower compared to leafy spurge; therefore, individual infested sites could be mapped.

The overall area of each infested leafy spurge and Canada thistle site was estimated by measuring the long- and short-axis of the infested area. Small areas $(<10 \mathrm{~m}$ wide) were measured with a fiberglass tape measure. Larger areas were estimated using a rangefinder which was periodically checked with a tape measure. The following information was recorded at each site: 1) a list of exotic species and their relative abundances, which was leafy spurge in most cases, 2) a list of native species and their relative abundances, 3 ) the position of the infested site on the landscape, and 4) the proportion of the landscape component infested by exotics. The area 
Table 1. Exotic plants of Theodore Roosevelt National Park prepared from the preliminary park flora, Stevens (1963) and Flora of the Great Plains (1986). Plant nomenclature follows that of Flora of Great Plains (1986). $\mathrm{NU}=$ North Unit, $\mathrm{SU}=$ South Unit.

Family/Scientific Name

Amaranthaceae

Amaranthus graecizans ${ }^{1 *}$

Amaranthus retroflexus ${ }^{1 *}$

Asteracea

Artemisia absinthinum ${ }^{1 *}$

Carduus nutans ${ }^{1 *}$

Centaurea maculosa

Centaurea repens

Cirsuim arvense

Lactuca serriola

Sonchus arvensis*

Taraxacum officinale

Tragopogon dubius

Boraginacea

Asperugo procumbens*

Lappula echinata

Brassiceae

Alyssum dessortum ${ }^{2 *}$

Camelina microcarpa*

Capsella bursa-pastoris

Conringia orientalis*

Descurainia sophia*

Lepidium perfoliatum

Sisymbrium altissumum*

Thlaspi arvense*

Caryophyllaceae

Silene cserei*

Silene pratensis*

\section{Chenopodiaceae}

Chenopodium album*

Chenopodium glaucum*

Kochia scoparia

Salsola iberica ${ }^{3}$

\section{Convoluvaceae}

Convoluvus arvensis
Prostrate pigweed

Redroot pigweed

Absinthse wormwood

Musk thistle

Spotted knapweed

Russian knapweed

Canada thistle

Prickly lettuce

Sow thistle

Common dandelion

Goatbeard/Salsify

Catchweed

Blue stickseed

Alyssum

False flax

Shepherd's purse

Hare's-ear mustard

Flixweed

Heart-leaved peppergrass

Tumbling mustard

Pennycress

Smooth catchfly

White campion

Lamb's quarters

Oak-leaved goosefoot

Burning bush/kochia

Russian thistle

X $\quad \mathrm{X}$

$\mathrm{X} \quad \mathrm{X}$

$\mathrm{X} \quad \mathrm{X}$

Field bindweed
$\mathrm{X}$

$\mathbf{X}$

X $\quad$ X

X $\quad \mathrm{X}$

X $\quad \mathrm{X}$

$\mathrm{X} \quad \mathrm{X}$

X $\quad \mathrm{X}$ 
Table 1. (continued).

\begin{tabular}{lll}
\hline Family/Scientific Name & Recorded in 1991 \\
\hline
\end{tabular}

\section{Eleagnaceae}

Eleagnus angustifolia

Russian olive

\section{Euphorbiaceae}

Euphorbia esula

Euphorbia $x$ psuedovirgata*

Leafy spurge

$\mathrm{X}$

\section{Fabaceae}

Medicago sativa

Melilotus alba

Melilotus officinalis

Trifolium repens*

Vicia sativa

Hybrid leafy spurge

\section{Lamiaceae}

Nepetea cataria

Alafala

White sweet clover

Yellow sweet clover

$\mathrm{X}$

White clover

$\mathrm{X} \quad \mathrm{X}$

\section{Liliaceae}

Asparagus officianalis

Common vetch

Catnip

\section{Malvaceae}

Malva parivifolia*

Malva rotunifolia ${ }^{1 *}$

Dwarf mallow

Poaceae

Agropyron cristatum

Agropyron repens*

Bromus inermis

Bromus japonicus

Bromus tectorum

Echinochloa crusgalli*

Poa bulbosa*

Poa compressa

Poa palustris*

Poa pratensis

Setaria viridis*

\section{Asparagus}

\section{Polygonaceae}

Polygonum achoreum* _ Knotweed

Rumex crispus

Rumex stenophyllus.

Crested wheatgrass

Quackgrass

Smooth brome

Japanese brome

Downy brome

Barnyard grass

Bulbous bluegrass

Canada bluegrass

Fowl bluegrass

Kentucky bluegrass

Green foxtail

$\begin{array}{ll}\mathrm{X} & \mathrm{X} \\ & \\ \mathrm{X} & \mathrm{X} \\ \mathrm{X} & \mathrm{X} \\ \mathrm{X} & \mathrm{X}\end{array}$

Curled dock

Dock

\section{Ranunculaceae}

Ranunculus scleratus

var scleratus

Cursed crowfoot 
Table 1. (continued).

\begin{tabular}{lll}
\hline Family/Scientific Name & Common Name & $\frac{\text { Recorded in 1991 }}{\text { NU SU }}$ \\
\hline
\end{tabular}

Scrophulariaceae

Linaria vulgaris*

Solanaceae

Hyoscyamus niger
Butter and eggs

Henbane

* Added to the preliminary exotic list that was initially provided by park personal

1 New to both the preliminary list and Heidel (1990) from collected specimen found in the North Unit

2 Listed in Caryophyllaceae by Heidel (1990)

3 Listed as Salsola kali in Heidel (1990)

infested by these two species along Jules Creek will be estimated during the next few months and incorporated into the 1992 annual report.

Other physiographic areas surveyed during the 1991 field season include the Achenbach Hills, Bottomland Grassland, Rolling Grasslands, Sagebrush Bottoms, Toeslopes and Upland Grasslands of the North Unit, and the Grassland Flats, Old River Terraces, Ridges and Ravines and Upland Grasslands of the South Unit. Several, randomly located sample sites were subjectively chosen within each physiographic unit selected for detailed study. An attempt was made to select specific study sites that represented the entire physiographic unit as a whole from heavily infested to non-infested. Two, parallel $25 \mathrm{~m}$ line transects were placed at each selected site. A $20 \times 50 \mathrm{~cm}$ quadrat was placed at $1 \mathrm{~m}$ intervals along each transect for a total of 50 quadrats per sample site. Each exotic plant species occurring in the quadrat was paced in a cover class as described by Daubenmire (1959). A two-meter belt transect recorded the occurrence of any exotic plant species not observed in the quadrats. This information is currently being summarized and will be incorporated into the 1992 annual report.

A total of 10 sites were sampled in the North Unit while 54 sites were sampled in the South Unit. Twenty-two species were recorded in both the North and South Units of the Park (Table 1). Japanese brome (Bromus japonicus) was the most frequently occurring species in the North Unit. The dominant exotic species found in the South Unit include
Japanese brome, smooth brome, downy brome $(B$. tectorum), and salsify (Tragopogon dubius).

Areas adjacent to developed roads were also examined in both the North and South Units. Variable length transects were sampled on both sides of the road at $1.6 \mathrm{~km}$ intervals beginning at the Park entrance for each Unit. Smooth brome was, by far, the most dominant exotic species found along the roadsides for both the North and South Unit.

Two sites were selected for preliminary evaluation of the ecological impact of four selected exotic species on the native constituents. The selected exotics include leafy spurge, smooth brome, japanese brome and downy brome. All three of the bromes were found in various degrees of infestation (light, moderate and heavy) on the area known as Johnson Plateau in the South Unit. An area near the Petrified Forest on the west side of the Little Missouri River was selected to evaluate the impact of leafy spurge on the native species.

Aboveground biomass, by species, was harvested from 30 subjectively placed $20 \times 50 \mathrm{~cm}$ quadrats for each of the four exotic species. The $\mathbf{3 0}$ quadrats were subjectively placed so that a range of infestations (light $=0 \%$ cover of exotic, moderate $=50 \%$ cover of exotic, and heavy $=100 \%$ cover of exotic) could be evaluated. Thus, 10 quadrats were clipped for each cover class of exotic species. Standard analysis of variance procedures were used to compare the effect of the exotics on biomass means. 
Total aboveground biomass was significantly higher $(P<0.05)$ on heavily infested sites (mean $=261$ $\mathrm{g} / \mathrm{m}^{2}$ ) for all four sites compared to both moderately infested (mean $=160 \mathrm{~g} / \mathrm{m}^{2}$ ) and non-infested sites $\left(\right.$ mean $\left.=145 \mathrm{~g} / \mathrm{m}^{2}\right)$. The dominant native species on non-infested sites found on Johnson Plateau were western wheatgrass (Agropyron smithii), blue grama (Bouteloua gracilis), threadleaf sedge (Carex filifolia) and needle-and-thread (Stipa comata). Considering all three species of brome collectively, the aboveground biomass of the major native species was substantially reduced by both moderate and heavy infestations (Figure 1). Smooth brome, the only perennial of the three species of brome examined, appeared to be the most detrimental to aboveground production. The biomass of most of the native species was significantly reduced $(\mathrm{P}<0.05)$ by only moderate amounts (50\% cover) of smooth brome. For the other two species of brome, significant reductions $(P<0.05)$ were observed only when cover values for the exotics approached 100 percent.

The dominant native species found associated with light, moderate and heavy infestations of leafy spurge on the west side of the River included needleand-thread, blue grama and threadleaf sedge. The aboveground biomass for needle-and-thread and blue grama were significantly reduced $(\mathrm{P}<0.05)$ by both moderate and heavy infestations of leafy spurge (Figure 1). However, threadleaf sedge was not impacted by even heavy infestations.

\section{- Literature Cited}

Great Plains Flora Association. 1986. Flora of the Great Plains. University Press of Kansas, Lawrence.

Heidel, B. 1990. Inventory of rare plant species in Theodore Roosevelt National Park. North Dakota Parks and Recreation Department, Bismarck.

Marlow, C.B, L.R. Irby and J.E. Norland. 1984. Optimum carrying capacity for bison in Theodore Roosevelt National Park. Report submitted to National Park Service. Montana State University, Bozeman.

Stevens, O.A. 1963. Handbook of North Dakota Plants. North Dakota Institute for Regional Studies, Fargo. 

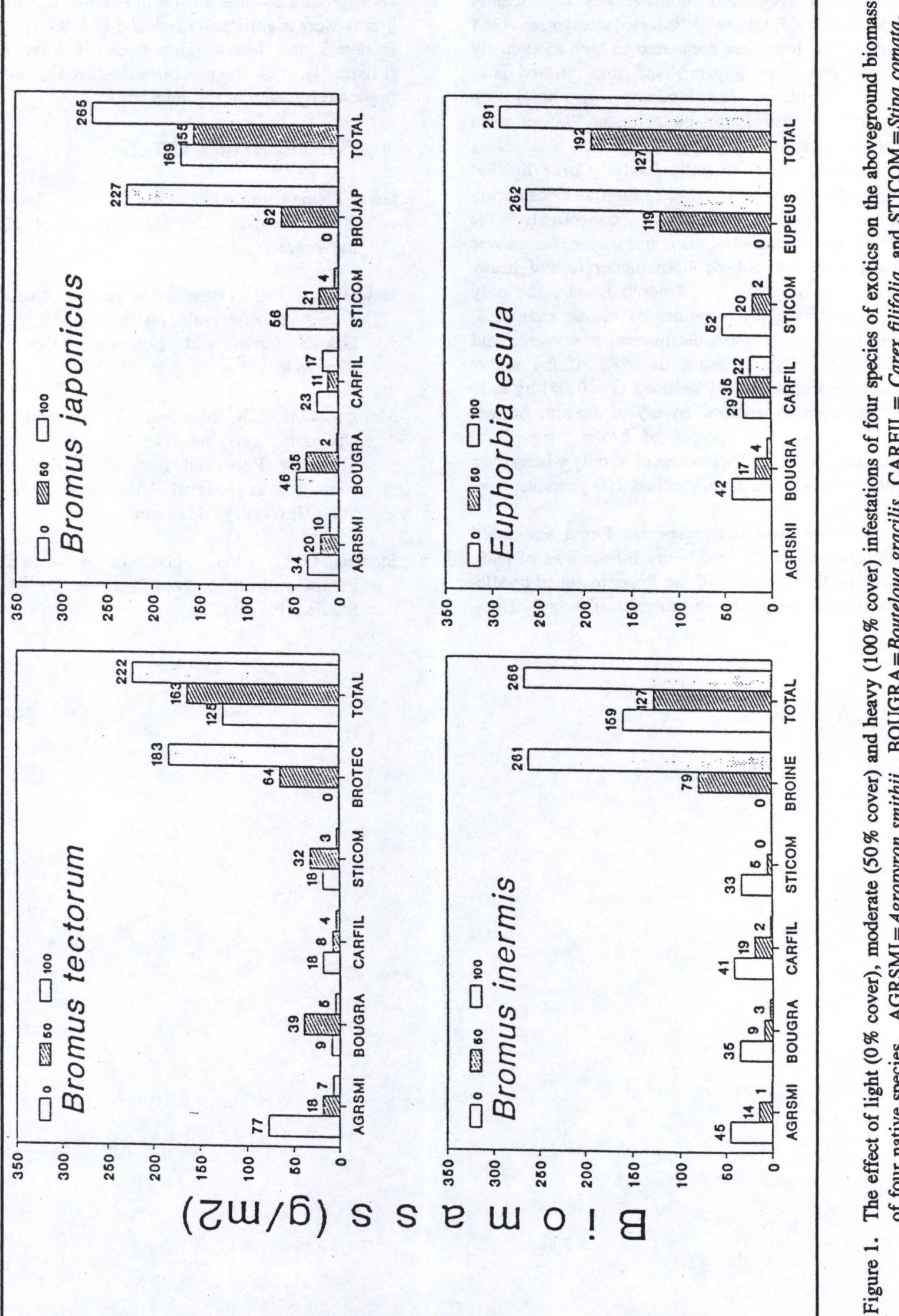